\title{
Michael Löwy
}

\section{Zachodni imperializm}

przeciwko pierwotnemu komunizmowi

- nowe odczytanie pism ekonomicznych

Róży Luksemburg*

Dyskusja na temat teorii imperializmu Róży Luksemburg dotyczy głównie argumentu ekonomicznego, w tym między innymi schematów reprodukcji, procesu cyrkulacji, konieczności istnienia rynków „zewnętrznych”. Istnieje jednak jeszcze inny jej wymiar, który wydaje się co najmniej tak samo istotny: zmagania imperializmu z przedkapitalistycznymi gospodarkami oraz bezlitosne niszczenie „naturalnych” i chłopskich gospodarek, stanowiących - w dużej części formy pierwotnego komunizmu. Zainteresowanie Luksemburg społeczeństwami pierwotnego komunizmu udokumentowane jest w jej Wstępie do ekonomii politycznej, a imperialistyczna wojna przeciwko nim omówiona jest zarówno w tej pracy, jak i w końcowych rozdziałach Akumulacji kapitatu. W jej refleksjach zarysowane zostało oryginalne podejście do formacji społecznych, będące przeciwieństwem linearnej, „progresywnej” perspektywy ideologii burżuazyjnej. Współczesne walki rdzennej ludności, na przykład walki przeciwko międzynarodowym firmom naftowym i wydobywczym w Ameryce Łacińskiej, ilustrują aktualność argumentu Róży Luksemburg w dwudziestym pierwszym wieku.

Słowa kluczowe: Róża Luksemburg, pierwotny komunizm, imperializm, modernizacja, nowoczesność

* Jest to rozszerzona wersja referatu wygłoszonego podczas konferencji Rosa Luxemburg: Theorie, Kontext, Aktualität-Zum 140. Geburtstag, zorganizowanej w Moskwie, w dniach 5-6 październik 2011. 
Fascynacja Róży Luksemburg przedkapitalistycznymi wspólnotami jest niezwykle rzadko dyskutowanym wątkiem jej dzieł ekonomicznych. Zacznijmy może zatem od jej Wstępu do ekonomii politycznej (Einführung in die Nationalökonomie), dzieła opublikowanego przez Paula Leviego w 1925 roku$^{1}$. Manuskrypt został naszkicowany w więzieniu w latach 1914-1915, w oparciu o notatki z prowadzonego przez nią w latach 1907-1914 kursu ekonomii politycznej w szkole partyjnej niemieckiej socjaldemokracji (SPD). Tekst ten bez wątpienia nie jest dziełem gotowym, jednakże zdumiewające jest w nim to, że rozdziały poświęcone społeczeństwu komunizmu pierwotnego oraz jego rozkładowi zajmują więcej przestrzeni, niż te dotyczące produkcji rynkowej oraz gospodarki kapitalistycznej razem wzięte. To nietypowe podejście do ekonomii politycznej jest prawdopodobnie powodem zlekceważenia tej pracy przez większość ekonomistów marksistowskich (Ernst Mandel, autor przedmowy do francuskiego wydania, jest tutaj wyjątkiem). Podobnie było nawet w wypadku biografów Róży Luksemburg (z wyjątkiem Paula Frölicha). Wagi tej pracy nie docenili również pracownicy Instytutu Marksa-Engelsa-Lenina-Stalina z Berlina Wschodniego, odpowiedzialni za ponowne wydanie tego tekstu w 1951 roku. W przedmowie piszą, że książka jest „popularną prezentacją podstawowych cech kapitalistycznego sposobu produkcji”, zapominając tym samym, że niemal połowa poświęcona jest formacjom przedkapitalistycznym. Analiza formacji społecznych nazywanych przez Luksemburg pierwotnymi spoteczenstwami komunistycznymi oraz przeciwstawienie ich kapitalistycznym społeczeństwom rynkowym są właściwie kluczowymi wątkami pracy². Tekst ten zarysowuje nowatorskie podejście do ewolucji formacji społecznych, sytuujące się w opozycji do linearnych, „progresywnych” ujęć ewolucjonistycznych.

Co kryje się za zainteresowaniem Luksemburg tak zwanymi wspólnotami pierwotnymi? Z jednej strony, oczywiste jest, że stara się ona

1 R.Luksemburg, Wstęp do ekonomii politycznej, tłum. B. Wścieklica, Warszawa 1959.

2 Egzemplarz, którym się tutaj posługuję, ma dość dziwną historię. Jest wyborem pism Róży Luksemburg opublikowanym przez Marx-Engels-Lenin-Stalin Institut beim $Z K$ der $S E D$, z przedmową Wilhelma Piecka, stalinowskiego przywódcy NRD, po której następują wprowadzenia autorstwa Lenina i Stalina, uwypuklające różne „błędy” żydowsko-polsko-niemieckiej rewolucjonistki. Zakupiłem tę książkę w antykwariacie, w Tel-Avivie i odkryłem, że posiadała odręczną dedykację następującej treści: „Przepraszamy, ale nie mogliśmy znaleźć wydania dzieł Róży Luksemburg pozbawionego tego zbytecznego "wprowadzenia«. Z serdecznymi pozdrowieniami, Tamara i Izaak. Throttle Green, 25 sierpnia 1957 roku”. Oczywiście autorami tego wpisu byli Tamara i Izaak Deutscherowie. 
wykorzystać samo istnienie tego typu archaicznych społeczeństw komunistycznych jako narzędzie do podważenia czy wręcz zniszczenia, „starego pojęcia wiecznej natury własności prywatnej i jej istnienia od początku świata" (Die alte Vorstellung von der Ewigkeit des Privateigentums und seinem bestehen von Anbeginn der Welt). Burżuazyjni ekonomiści nie mogą chociażby wyobrazić sobie wspólnotowej własności i zrozumieć niczego innego niż to, co przypomina cywilizację kapitalistyczną, a w konsekwencji z uporem odmawiają uznania historycznego zjawiska wspólnot. Z drugiej strony, Luksemburg postrzega pierwotny komunizm jako cenny historyczny punkt odniesienia dla krytyki kapitalizmu, odsłaniający jego irracjonalny, urzeczowiony, anarchiczny charakter i uwypuklający radykalną opozycję między wartością użytkową a wartością wymienną ${ }^{3}$. Celem Luksemburg jest zatem znalezienie i „ocalenie” wszystkiego, co w przeszłości mogło być, przynajmniej w pewnym stopniu, zapowiedzią współczesnego socjalizmu.

Podobnie jak Marks i Engels, Luksemburg spogląda uważnie na pisma historyka Georga Ludwiga von Maurera dotyczące archaicznej wspólnoty germańskiej (Mark); podobnie do nich zdumiewał ją demokratyczny i egalitarny sposób funkcjonowania tej komunistycznej formacji oraz jej spoteczna przejrzystośc ${ }^{4}$ :

Niepodobna wyobrazić sobie nic bardziej prostego i harmonijnego, niż ten system gospodarczy dawnej marki germańskiej. Cały mechanizm życia społecznego widoczny jest tu jak na dłoni. Ścisły plan i surowy porządek decydują o postępowaniu każdego; czynią z niego cząstkę jednej wielkiej całości. Bezpośrednie potrzeby życia codziennego wszystkich członków i ich jednakowe zaspokajanie jest punktem wyjścia i celem całej organizacji. Wszyscy pracują wspólnie dla wszystkich i decydują o wszystkim gromadnie. Skąd jednakże wypływa i na czym się opiera ta organizacja i władza ogółu nad jednostką? Jest to po

3 W swojej przedmowie do przekładu francuskiego Ernst Mandel zauważa, że „wyjaśnienie fundamentalnych różnic między gospodarką opartą na produkcji wartości dodatkowych, przeznaczonych do zaspokajania potrzeb produkcji a gospodarką opartą na produkcji dóbr, zajmuje większą część książki” E. Mandel, Préface, [w:] R.Luxemburg, Introduction à l'économie politique, Paris 1970, s. xviii.

4 Zob. również interesujący artykuł Petera Hudisa dotyczący świata niezachodniego w pismach Róży Luksemburg, w którym skupia się on przede wszystkim na różnicach między podejściami jej i Marksa do rosyjskich wspólnot rolniczych. P. Hudis, Neue Einschätzungen zu Rosa Luxemburgs Schriften über die Nich-Westliche Welt, [w:] China entdeckt Rosa Luxemburg: Internationale RosaLuxemburg-Gesellschaft in Guangzhou, red. N. Ito, T. Bergmann, S. Hochstadt, O.Luban, Berlin 2007.
Luksemburg postrzega pierwotny komunizm jako cenny historyczny punkt odniesienia dla krytyki kapitalizmu, odsłaniający jego irracjonalny, urzeczowiony, anarchiczny charakter i uwypuklający radykalną opozycję między wartością użytkową a wartością wymienną 
prostu komunistyczne władanie ziemią, to znaczy wspólne posiadanie przez pracujących najważniejszych środków produkcji 5 .

Luksemburg podkreśla cechy tej wspólnotowej formacji, które odróżniaja ja od kapitalizmu i stanowią o jej wyższości - pod pewnymi względami - nad nowoczesną cywilizacją burżuazyjną: „Przed dwoma tysiącami lat i jeszcze wcześniej, [...] panowały u Germanów porządki zasadniczo różne od dzisiejszych. Germanowie nie znali wtedy państwa z przymusowymi prawami pisanymi, nie znali podziału na biednych i bogatych, panujących i pracujących" ${ }^{\circ}$.

Opierając się na pracy rosyjskiego historyka Maksyma Kowalewskiego, którego pracami wcześniej interesował się również Marks, Luksemburg podkreśla uniwersalność wspólnoty rolniczej jako podstawowej formy ludzkiego społeczeństwa w pewnej fazie jego rozwoju, uwidaczniającej się w społecznościach amerykańskich Indian, Inków czy Azteków, jak również Kabylów, plemion afrykańskich czy Hindusów. Przykład peruwiański wydaje się najistotniejszy i również tutaj Luksemburg nie może się powstrzymać od porównania inkaskiej Marci z „cywilizowanym” społeczeństwem: „Dzisiejsza sztuka karmienia się wyłącznie owocami cudzej pracy i czynienia ze swego próżniactwa nieodłącznej właściwości panowania obca była jeszcze tej organizacji społecznej, gdzie wspólna własność i powszechny obowiązek pracy należały do głęboko zakorzenionych obyczajów ludowych". Jednocześnie manifestuje swój podziw dla „niesamowitego oporu ludu indiańskiego i instytucji agrarnego komunizmu, których, pomimo warunków, szczątki zostały zachowane jeszcze w XIX wieku"7. Jakieś dwadzieścia lat później wybitny peruwiański myśliciel marksistowski José Carlos Mariategui rozwinął tezę uderzająco zbieżną z koncepcjami Luksemburg, chociaż najprawdopodobniej nie był zaznajomiony z jej komentarzami na temat Peru: aby pozyskać masy chłopskie, współczesny socjalizm musi zwrócić się w stronę rdzennych tradycji, odwołujących się do inkaskiego komunizmu.

Najważniejszym autorem w tym obszarze dla Luksemburg, podobnie jak dla Marksa i Engelsa, był amerykański antropolog Lewis Morgan. Odwołując się do jego klasycznej pracy Spoteczeństwo pierwotne ${ }^{8}$, Luksemburg idzie dalej niż Marks i Engels, rozwijając całą imponującą wizję

5 R.Luksemburg, Wstęp do ekonomii politycznej..., s. 164-165.

6 Tamże, s. 90-91.

7 Tamże, s. 168.

8 L.H.Morgan, Spoteczeństwo pierwotne czyli Badanie kolei ludzkiego postępu od dzikości przez barbarzyństwo do cywilizacyi, tłum. A. Bąkowska, Warszawa 1887. 
historii, heterodoksyjną koncepcję odwiecznej ewolucji ludzkości, w której współczesna cywilizacja „z jej własnością prywatną, dominacją klasową i męską, jej niewolącym Państwem i małżeństwem” wydaje się zwykłą parentezą, okresem przejściowym między społeczeństwem pierwotnego komunizmu a komunistycznym społeczeństwem przyszłości. Rewolucyjna idea łączności między przeszłością a przyszłością leży w samym centrum tej wizjonerskiej perspektywy:

Szlachetna tradycja zamierzchłej przeszłości podaje w ten sposób rękę rewolucyjnym dążeniom przyszłości, krąg poznania zamyka się harmonijnie i z tej perspektywy dzisiejszy świat panowania klasowego i wyzysku - który przypisuje sobie rolę alfy i omegi całej kultury, najwyższego rzekomo celu świata - okazuje się po prostu nieznacznym, przejściowym etapem wielkiego pochodu kulturalnego ludzkości.

Z tego punktu widzenia, europejska kolonizacja ludów Trzeciego Świata raziła Luksemburg jako przedsięwzięcie całkowicie nieludzkie i społecznie destruktywne. Angielska okupacja Indii była tu wiele mówiącym przykładem: spustoszyła i zlikwidowała tradycyjne komunistyczne struktury agrarne, przynosząc tragiczne konsekwencje dla chłopstwa. Róża Luksemburg współdzieliła Marksowskie przekonanie, jakoby imperializm przynosił skolonizowanym narodom postęp gospodarczy, nawet jeśli dzieje się to przy wykorzystaniu „niegodziwych metod społeczeństwa klasowego". Jednakże podczas gdy Marks - bez ukrywania swojego oburzenia takimi metodami - podkreślał gospodarczo postępową rolę kolei wprowadzonych przez Anglików w Indiach, Luksemburg kładła większy nacisk na spotecznie szkodliwe konsekwencje kapitalistycznego „postępu”:

Dawne więzi zostały pozrywane, spokojne oderwanie komunizmu od świata zastąpione przez waśnie, niezgodę, nierówności i wyzysk. Z jednej strony, powstały olbrzymie latyfundia, z drugiej zaś pojawiła się ogromna, wielomilionowa rzesza pozbawionych środków do życia chłopów-dzierżawców. Własność prywatna święciła swoje wtargnięcie do Indii, a wraz z nią tyfus głodowy i szkorbut, które stały się stałymi gośćmi w dolinie Gangesu ${ }^{10}$.

Ta różnica względem Marksa odpowiada pewnie odmiennemu etapowi historycznemu, który umożliwił nowe spojrzenie na skolonizowane kraje, ale jest też ona wyrazem szczególnego uwrażliwienia Luksemburg na społeczne i ludzkie cechy wspólnot pierwotnych.

9 R.Luksemburg, Wstęp do ekonomii politycznej..., s. 111.

10 Tamże, s. 98. 
Ten argument rozwijany jest nie tylko we Wstępie do ekonomii politycznej, lecz również w Akumulacji kapitatu, gdzie Luksemburg ponownie krytykuje historyczną rolę angielskiego kolonializmu i wyraża oburzenie karygodną pogardą, którą europejscy zaborcy okazali wobec starego systemu irygacji. Kapitał w swojej ślepej i nieokiełznanej chciwości, „nie jest w stanie rozpoznać wartości wynalazków ekonomicznych starszej cywilizacji”" upadku tego tradycyjnego systemu, a w rezultacie - począwszy od 1867 roku - do głodu pociągającego za sobą miliony ofiar w Indiach. Podobnie jak w przypadku francuskiej kolonizacji Algierii, którą Luksemburg postrzegała jako systematyczne i rozmyślne dążenie do zniszczenia wspólnotowej własności, prowadzące do gospodarczej ruiny rdzennych populacji.

W rozdziale XXVII Akumulacji kapitatu, zatytułowanym Walka z gospodarka naturalna, Luksemburg wskazuje, że wszystkie europejskie przedsięwzięcia kolonialne dzielą podobną, brutalną strategię wykorzeniania przedkapitalistycznych, rdzennych struktur społecznych:

\begin{abstract}
A że właśnie prymitywne związki tubylców stanowią najsilniejszą zaporę ochraniającą zarówno społeczeństwo jak i podstawy jego egzystencji materialnej, przeto kapitał nasamprzód systematycznie i planowo burzy i niszczy niekapitalistyczne organizmy społeczne, które napotyka w toku swej ekspansji [...]. Każdemu nowemu rozszerzeniu posiadłości kolonialnych towarzyszy siłą rzeczy uporczywa wojna kapitału przeciw ekonomicznym i społecznym stosunkom tubylców oraz zagarnianie przemocą ich środków produkcji i sił roboczych ${ }^{12}$.
\end{abstract}

Marks zdążył skrytykować przemoc polityk kolonialnych już w rozdziale Kapitatu zatytułowanym Akumulacja pierwotna. Nowy argument wysunięty przez Różę Luksemburg głosi, że akumulacja pierwotna jest permanentna cecha imperialistycznej ekspansji, od szesnastego wieku aż do dziś:

Kapitał nie zna innej drogi rozwiązywania tego problemu prócz przemocy - stałe metody akumulacji kapitału jako procesu historycznego, metody stosowanej nie tylko przy narodzinach kapitalizmu, ale aż do dziś dnia. [...] Metoda przemocy jest tu bezpośrednim następstwem starcia się kapitalizmu z zakreślającymi granice jego akumulacji formacjami opartymi na gospodarce naturalnej. [...]

11 R. Luksemburg, Akumulacja kapitatu: przyczynek do ekonomicznego wyjaśnienia imperializmu, tłum. J. Maliniak, Z. Kluza-Wołosiewicz, J. Nowacki, Warszawa 2011, s. 464.

12 Tamże, s. 457. 
Klasyczne przykłady stosowania tych metod daje polityka Anglików w Indiach i Francuzów w Algierii ${ }^{13}$.

Podczas gdy głównym pojęciem używanym przez Luksemburg do zdefiniowania tych przedkapitalistycznych struktur $\mathrm{w}$ tym rozdziale, a w zasadzie przez większą część książki, jest pojęcie „gospodarki naturalnej”, od czasu do czasu odwołuje się ona również do komunizmu. Dzieje się tak, gdy opisuje „prastarą organizację gospodarczą Hindusów - komunistyczną wspólnotę gminną", która „utrzymała się w swych różnorodnych formach przez całe tysiąclecia i mimo wszelkich burz na "niebosiężnych wyżynach politycznych " przebyła długą historię wewnętrzną", jednak została ostatecznie przerwana przez brytyjski kolonializm ${ }^{14}$. Podobnie, kiedy omawia francuską politykę kolonialną w Afryce Północnej: „Planowe i świadome niszczenie i dzielenie własności wspólnej - oto nieuchronny biegun, na który w ciągu pół wieku [...] skierowana była igła kompasu francuskiej polityki kolonialnej”'15, jednak ostatecznie skończyła się niepowodzeniem, „rozbijając się o trudności wprowadzenia za jednym zamachem burżuazyjnej własności prywatnej w pierwotnych komunistycznych związkach wielkich rodzin"16.

W większości przywoływanych przez nią przykładów omawiany jest europejski kolonializm, jednak wskazuje ona także na zbieżność pomiędzy ekspansjonistycznymi strategiami Stanów Zjednoczonych a ich bezlitosną walką przeciwko rdzennym wspólnotom:

W 1825 roku za prezydentury Monroego Kongres postanowił przesiedlić Indian z obszarów na wschód od Missisipi na obszary położone na zachód od tej rzeki. Czerwonoskórzy bronili się rozpaczliwie, usunięto ich jednak - przynajmniej te resztki, które ocalały od krwawych rzezi 40 wojen indiańskich - jak uciążliwe rupiecie, by stłoczyć tu jak zwierzynę w ogromnych »reserwatach ${ }^{17}$.

Poza konkretnymi przykładami, Luksemburg krytykowała też system kolonialny w całości - czy był on hiszpański, portugalski, holenderski, angielski, amerykański, niemiecki, czy miał miejsce w Afryce, Azji, czy w Amerykach. Przyjmowała punkt widzenia ofiar kapitalistycznej modernizacji. Jak podkreśla we Wstępie do ekonomii politycznej:

13 Tamże, s. 458.

14 Tamże, s. 458-459.

15 Tamże, s. 469.

16 Tamże, s. 475.

17 Tamże, s. 495. 
Dla ludów pierwotnych w krajach kolonialnych, gdzie niegdyś panował pierwotny komunizm, nowoczesny kapitalizm tworzy nagłą katastrofę, niewyrażalne nieszczęście pełne najstraszliwszego cierpienia ${ }^{18}$.

Według niej, walka rdzennych populacji przeciwko imperializmowi jest wyrazem nad podziw nieustępliwego oporu starych tradycji komunistycznych przeciwko zachłannemu poszukiwaniu zysków, brutalnie narzuconemu przez kapitalistyczną „europeizację"
Według niej, walka rdzennych populacji przeciwko imperializmowi jest wyrazem nad podziw nieustępliwego oporu starych tradycji komunistycznych przeciwko zachłannemu poszukiwaniu zysków, brutalnie narzuconemu przez kapitalistyczną „europeizację”. Burżuazja instynktownie zrozumiała mroczne powiązanie pomiędzy oporem pradawnego komunizmu oraz „nową Ewangelią mas proletariackich” w Europie. W związku z tym, Francuskie Zgromadzenie Narodowe obstawało w 1873 roku - zaledwie kilka lat po masakrze Komuny Paryskiej - przy tym, żeby pradawne formy własności w Algierii zostały zniszczone, ponieważ „podtrzymują w umysłach tendencje komunistyczne" ${ }^{19}$. Między wierszami można zatem rozpoznać tutaj ideę sojuszu między antykolonialnymi walkami skolonizowanej ludności oraz antykapitalistycznymi walkami nowoczesnego proletariatu, widzianego jako sojusz między nowym a starym komunizmem.

Czy oznacza to, jak wierzy Gilbert Badia - autor wybitnej biografii Róży Luksemburg oraz jeden z nielicznych uczonych, który krytycznie przebadał ten aspekt jej dzieła - że przedstawia ona pradawne struktury skolonizowanych społeczeństw w przesadnie jednoznacznym, „czarno-białym kontraście z kapitalizmem”? Jego zdaniem, Luksemburg przeciwstawia stare wspólnoty „obdarzone niemal każdą cnotą i rozumiane jako rzeczywiście nieruchome”, „destrukcyjnym funkcjom kapitalizmu, który nie ma już dłużej jakichkolwiek progresywnych cech”. W ten sposób znajdujemy się z dala od zwycięskiej burżuazji przywołanej przez Marksa w Manifeście ${ }^{20}$.

Wydaje się, że zastrzeżenia te są nieuzasadnione. Po pierwsze, Róża Luksemburg nie opisywała dawnych wspólnot w kategoriach statycznych; wprost przeciwnie, wskazywała na ich sprzeczności i przekształcenia. Podkreślała, że „powstanie nierówności i despotyzmu jest wynikiem samego rozwoju wewnętrznego pierwotnego społeczeństwa komunistycznego" ${ }^{21}$. Po drugie, nie zaprzeczała istnieniu gospodarczo postępowej roli kapitalizmu, jednakże krytykowała niegodziwe i społecznie

18 R. Luksemburg, Wstęp do ekonomii politycznej..., s. 114

19 Tamże, s. 113.

20 G. Badia, Rosa Luxemburg, journaliste, polémiste, révolutionnaire, Paris 1975, s. 498, 501.

21 R. Luksemburg, Wstęp do ekonomii politycznej..., s. 212. 
regresywne aspekty kapitalistycznej kolonizacji. Po trzecie, uwypuklała najbardziej pozytywne aspekty pierwotnego komunizmu, ale w odróżnieniu od cywilizacji burżuazyjnej udało się jej również wskazać na jego wady i ograniczenia: lokalna, ciasna perspektywa, niski poziom produktywności pracy oraz dążeń cywilizacyjnych, bezsilność wobec natury, brutalna przemoc oraz permanentny stan wojny między wspólnotami ${ }^{22}$. Po czwarte, podejście Luksemburg jest w istocie odmienne od tego, które przyjął Marks w 1848 roku, w swoim hymnie na cześć burżuazji; jest ono raczej bliskie temu z podrozdziału o Genezie kapitalisty przemystowego, z rozdziału XXIV Kapitatu, gdzie Marks opisuje „barbarzyństwa” i „okrucieństwa” europejskiej kolonizacji.

Ponadto, pogląd Luksemburg na kwestię rosyjskiej wspólnoty wiejskiej jest dużo bardziej krytyczny niż ten przyjmowany przez Marksa. Biorąc za punkt wyjścia analizy Engelsa z końca dziewiętnastego wieku dotyczące upadku obszcziny, podkreślała ona historyczne ograniczenia tradycyjnych wspólnot i konieczność ich przekroczenia ${ }^{23}$. Następnie, spoglądając w przyszłość, nie zgadzała się z rosyjskimi populistami, obstając przy „zasadniczej różnicy między socjalistyczną gospodarką światową przyszłości a prymitywnymi grupami komunistycznymi zamierzchłej przeszłości"24.

Tak czy inaczej, pisma Luksemburg na ten temat są czymś więcej, niż erudycyjnym spojrzeniem na historię gospodarczą; podsuwają nam inny sposób pojmowania przeszłości i teraźniejszości, społecznej zmienności, postępu i nowoczesności. Poprzez konfrontowanie kapitalistycz-

22 Tamże, s. 169-170.

23 „Na rosyjskiej spólnocie wioskowej kończy się bieg zmiennych losów pierwotnego komunizmu agrarnego; krąg się zamyka. Zrodzona jako naturalny produkt rozwoju społecznego, jako najlepsza rękojmia postępu gospodarczego oraz materialnego i duchowego rozkwitu społeczeństwa - spólnota wioskowa dokonuje tu swego żywota, używana i nadużywana jako narzędzie zacofania politycznego i ekonomicznego. To, że chłop rosyjski chłostany był rózgami przez swoich współtowarzyszy, w celu przypodobania się absolutyzmowi carskiemu, przemawia jak najsurowsza krytyka historyczna ciasnych ram komunizmu pierwotnego i jest najdobitniejszym wyrazem faktu, że i ta forma społeczna podlega zasadzie dialektycznej: to, co rozumne, staje się absurdem, co dobre - utrapieniem." (R. Luksemburg, Wstęp do ekonomii politycznej..., s. 202). Peter Hudis w swoim eseju omawia rozbieżności między krytycznym ujęciem rosyjskiej wspólnoty w wykonaniu Róży Luksemburg oraz dużo bardziej przychylnym spojrzeniu Marksa z jego szkicu listu do Wiery Zasulicz. Zob. P.Hudis, Neue Einschätzungen... oraz K. Marks, Szkice pierwotne listu do Wiery Zasulicz, [w:] MED, t. 19, Warszawa 1972, s. 430-454.

24 R. Luksemburg, Wstęp do ekonomii politycznej..., s. 159. 
nej cywilizacji przemysłowej ze wspólnotową przeszłością ludzkości Róża Luksemburg zrywa z linearnym ewolucjonizmem, pozytywistycznym „progresywizmem” oraz ze wszystkimi dominującymi dzisiaj, banalnie „modernizującymi” interpretacjami marksizmu.

Dzisiejsze walki rdzennej ludności - na przykład w Ameryce Łacińskiej, przeciwko multinarodowym kompaniom naftowym czy wydobywczym - potwierdzają aktualność argumentu Róży Luksemburg w dwudziestym pierwszym wieku. Czy rdzenne wspólnoty w meksykańskim Chiapas, w andyjskich pasmach Peru, Boliwii i Ekwadoru lub w lasach amazońskich Peru i Brazylii są pozostałościami „pierwotnego komunizmu”? W każdym z tych przypadków walki toczone są w imię własnych wspólnotowych tradycji, tworzą kolektywną, społeczną i gospodarczą organizację, będąc $\mathrm{w}$ harmonii ze środowiskiem naturalnym oraz - podobnie jak siostrzane ruchy z innych kontynentów - występują przeciwko destrukcyjnym przedsięwzięciom prowadzonym w imię „wzrostu”, „modernizacji” czy „postępu” przez lokalne lub multinarodowe przedsiębiorstwa agrobiznesowe, kompanie naftowe czy wielkich hodowców bydła. Opór chłopów i rdzennych wspólnot przeciwko brutalnym i pełnym przemocy formom permanentnej akumulacji pierwotnej trwa do dziś... 
Michael Löwy (ur. 1938) - socjolog i filozof. Emerytowany profesor socjologii w Centre National de la Recherche Scientifique i wykładowca École des Hautes Études en Sciences Sociales w Paryżu. Autor ponad dwustu publikacji z dziedziny socjologii kultury i filozofii polityki, poświęconych między innymi twórczości Benjamina, Kafki, Lukácsa i Marksa. Jego najważniejsze książki to: Georg Lukács: from Romanticism to Bolshevism (1979), Redemption and Utopia: Jewish Libertarian Thought in Central Europe: a Study in Elective Affinity (1992), On Changing the World. Essays in political philosophy: from Karl Marx to Walter Benjamin (1993), Fire Alarm: Reading Walter Benjamin's "On the Concept of History" (2005), The Theory of Revolution in the Young $\operatorname{Marx}(2006)$.

\section{Dane adresowe autora:}

Michael Löwy

Le Centre d'Études Interdisciplinaires des Faits Religieux

(École des Hautes Études en Sciences Sociales)

10, rue Monsieur le Prince

75006 - PARIS - FRANCE

e-mail: michael.lowy@orange.fr

\section{Cytowanie:}

M. Löwy, Zachodni imperializm przeciwko pierwotnemu komunizmowi - nowe odczytanie pism ekonomicznych Róży Luksemburg, „Praktyka Teoretyczna” nr 6/2012, http://www.praktykateoretyczna.pl/PT nr6 2012 Roza Luksemburg/16.Lowy.pdf (dostęp dzień miesiąc rok)

\section{Author: Michael Löwy}

Title: Western Imperialism Against Primitive Communism. A New Reading of Rosa Luxemburg's Economic Writings

Summary: The discussion on Rosa Luxemburg's theories of imperialism has mainly focused on the economic argument - the schemes of reproduction, the process of circulation, the need for "external" markets, etc. There is however another dimension, at least as important : the struggle of imperialism against pre-capitalist economies, the ruthless destruction of "natural" and peasant economies, many of them being forms of primitive communism. Luxemburg's interest for primitive communist societies is documented by her Introduction to Political Economy and the imperialist war against them is discussed both in this work and in the last chapters of The Accumulation of Capital. A wholly original approach to the evolution of social formations, running counter to linear "progressive" views of bourgeois ideology, is outlined in these reflections. 
Present indigenous struggles e.g. in Latin America, against multinational oil or mining companies, illustrate the topicality of Rosa Luxemburg's argument in the 21 th century.

Keywords: Rosa Luxemburg, primitive communism, imperialism, modernization, modernity 